\title{
Pengaruh Penambahan Tepung Daun Kelor pada Pakan terhadap Kadar Kreatinin dan Urea Serum Tikus Wistar
}

\author{
(THE INFLUENCE OF MORINGA OLEIFERA LEAF FLOUR ADDITION TO KREATININ \\ AND UREA SERUM LEVELS OF WISTAR RATS)
}

\author{
Yoviniani Narti Dosom ${ }^{1 *}$, I Nyoman Suarsana ${ }^{2}$, Ni Luh Eka Setiasih ${ }^{3}$ \\ ${ }^{1}$ Praktisi Dokter Hewan di Kabupaten Manggarai Nusa Tenggara Timur. \\ ${ }^{2}$ Laboratorium Biokimia Veteriner, Fakultas Kedokteran Hewan, Universitas Udayana, \\ Denpasar-Bali. ${ }^{3}$ Laboratorium Histologi Veteriner, Fakultas Kedokteran Hewan, Universitas \\ Udayana, Denpasar-Bali. \\ *Email: dosomyoviniani@gmail.com
}

\begin{abstract}
ABSTRAK
Tanaman kelor (Moringa oleifera) telah lama dikenal masyarakat dan telah lama pula digunakan sebagai obat tradisional dan dikonsumsi sebagai sayur serta pakan untuk ternak. Tepung daun kelor sendiri memiliki beberapa zat hypotensif, antikanker, antioksidan dan antibakterial. Penelitian ini bertujuan untuk mengetahui pengaruh penambahan tepung daun kelor terhadap kadar kreatinin dan urea darah tikus wistar. Sampel yang dipakai adalah 20 ekor tikus putih galur wistar (Rattus novergicus) betina yang berumur 1-1,5 bulan dan memiliki berat badan 50-80 gram. Dua puluh ekor tikus wistar tersebut dibagi ke dalam 5 kelompok perlakuan. Kelompok tersebut dibedakan berdasarkan konsentrasi tepung daun kelor yaitu 0\%, 2.5\%, 5\%, 10\% dan 20\%. Perlakuan dilakukan selama satu bulan, kemudian darah tikus wistar diambil untuk dianalisis kadar urea dan kreatinin serumnya. Data kadar kreatinin dan urea dianalisis mengunakan sidik ragam (ANOVA), dan bila perlakuan berpengaruh nyata dilanjutkan dengan uji Duncan dengan tingkat kepercayaan 5\%. Hasil dari penelitian ini adalah pada konsentrasi 5\% kadar kreatinin mengalami penurunan jika dibandingkan dengan kelompok kontrol (0\%). Pada kadar 2,5\%, $10 \%$ dan 20\% mengalami kenaikan jika dibandingkan dengan kelompok kontrol, tetapi kadar $10 \%$ lebih rendah dibandingkan kadar 2,5\% dan 20\%. Sedangkan, pada kadar urea serum tikus kelompok dosis 2,5\% dan $5 \%$ mengalami penurunan dibandingkan dengan kelompok kontrol. Kelompok $10 \%$ dan $20 \%$ mengalami kenaikan dibandingkan kelompok kontrol dan kelompok dosis $10 \%$ mengalami kenaikan yang signifikan.
\end{abstract}

Kata kunci: Ginjal; kadar kreatinin; kadar urea; daun kelor

\begin{abstract}
Moringa oleifera has long been known to the public and has long been used as a traditional medicine and consumed as a vegetable and feed for livestock. Moringa leaf flour itself has several hypotensive substances, anticancer, antioxidant, and antibacterial. This study aims to determine the effect of moringa leaf flour addition to creatinine and blood urea levels of wistar rats. The samples were 20 male wistar (Rattus novergicus) female rats aged 1-1,5 months and had 50-80 gram weight The twenty wistar rats were divided into five groups of treatments. The group is differentiated based on the concentration of moringa flour which is $0 \%, 2.5 \%, 5 \%, 10 \%$ and $20 \%$. The treatment was administered for one month, then the blood of the wistar rat was taken to be analyzed for serum urea and creatinine serum of wistar rats. The data of creatinine and urea were analyzed using variance (ANOVA). The treatment significantly affected the Duncan test with a 5\% confidence level The results of this study were at concentrations of 5\% creatinine levels decreased when compared with the control group. At $2.5 \%, 10 \%$ and $20 \%$ increased when compared to the control group, but $10 \%$ lower than $2.5 \%$ and $20 \%$. Meanwhile, in the serum urea concentration of rat, the dose group of $2.5 \%$ and $5 \%$ decreased compared to the control group. The $10 \%$ and $20 \%$ groups increased compared to the control group and the $10 \%$ dose group experienced a significantly increased.
\end{abstract}

Keywords: Kidney; kraetinin levels; urea levels; Moringa oleifera leaf 


\section{PENDAHULUAN}

Indonesia kaya akan keanekaragaman hayati berupa plasma nutfah flora dan fauna yang berpotensi sebagai bahan obat alam. Salah satunya adalah tanaman kelor (Moringa oleifera) yang telah lama dikenal di masyarakat sebagai tanaman sayur dan obat. Kelor merupakan tanaman yang dapat dijumpai dengan mudah di dataran rendah dan memiliki banyak manfaat. Tanaman kelor mulai dari akar, batang, daun, dan juga biji memiliki khasiat dan kegunaan sebagai obat secara empiris.

Tanaman daun kelor juga bisa dikonsumsi oleh manusia dan hewan. Berhubungan dengan hewan, daun kelor dapat dikelola dan dicampurkan pada pakan hewan. Hal ini dikarenakan daun kelor memiliki banyak manfaat termasuk kandungan zat dalam tanaman kelor begitu banyak dan bermanfaat bagi tubuh (Wihastuti dkk., 2007). Tanaman kelor mengandung zat kimia, seperti minyak behen, minyak terbang, emulsin, alkaloida, serta vitamin A, B1, B2, dan C (Dubey dkk., 2013). Selain itu kelor juga mengandung lebih dari 90 nutrisi disebut antioksidan alami terbaik. Memiliki sumber serat kasar terbaik, kandungan betakaroten 4 kali lipat lebih tinggi dari wortel juga terdapat bahan minyak Omega-3 dan klorofil (Wahyuni, 2013).

Daun kelor telah dilaporkan menjadi sumber yang kaya $\beta$-karoten, protein, vitamin $C$, kalsium dan kalium, dan menjadi sumber makanan yang baik sebagai antioksidan alami, karena adanya berbagai jenis senyawa antioksidan seperti asam askorbat, flavonoid, fenolat dan karotenoid (Anwar et al., 2007). Tepung daun kelor memiliki beberapa zat hypotensif, antikanker, dan antibakterial antara lain, niacimicin dan pteryangospermin. Selain itu daun kelor juga memiliki zat antioksidan antara lain sitosterol dan glukopyranoside (Guevara et al., 1999). Kandungan zat tersebut dapat berpengaruh pada organ manusia atau hewan yang mengkonsumsi daun kelor tersebut. Salah satu organ yang dapat dipengaruhi adalah ginjal, karena ginjal sangat berkaitan dengan makanan dan minuman yang dikomsumsi.

Ginjal merupakan organ vital yang sangat penting bagi tubuh. Fungsi ginjal adalah mengekskresikan zat sisa yang tidak dibutuhkan dalam tubuh seperti urea, asam urat, kreatinin, dan zat lain yang bersifat racun, serta mengatur volume plasma darah, keseimbangan cairan tubuh, dan mengatur ekskresi garam-garam. Konsentrasi urea, Blood Urea Nitrogen (BUN), kreatinin, amonia, ginjal sangat berkaitan dengan makanan dan minuman yang dikonsumsi (Laksmi et al., 2014). Pada kasus gangguan ginjal yang parah, kadar kreatinin dan BUN sangat meningkat. Oleh karena itu pemeriksaan BUN dan kreatinin dapat digunakan sebagai acuan untuk mengetahui terjadinya gangguan pada ginjal. Guna mengetahui fungsi ginjal, analisis BUN dan kreatinin dapat dilakukan pada darah dan urin (Alunat et al., 2014).

Kajian ilmiah tentang efek samping dari konsumsi kelor terhadap fungsi ginjal belum pernah dilaporkan. Penelitian ini bertujuan untuk menguji pengaruh pemberian tepung daun kelor pada pakan tikus terhadap kadar kreatinin dan urea serum tikus.

\section{METODE PENELITIAN}

\section{Materi Penelitian}

Dalam penelitian ini digunakan 20 ekor tikus putih Wistar betina, tepung daun kelor (Moringa oleifera), pakan tikus jenis HIGRO medicated 552, alkohol, kapas, aquadest, blender, kit Fluitest CREA kinetik, dan kit Fluitest UREA UV. Alat yang digunakan kandang hewan, alas kandang, blender, ayakan, mikro hematokrit, spektrofotometer, sentrifugasi, mikro pipet, tabung, sarung tangan dan masker.

\section{Metode Penelitian}

Penelitian eksperimental ini menggunakan Rancangan Acak Lengkap, dimana 20 ekor tikus wistar dibagi secara acak ke dalam 5 kelompok perlakuan, sehingga masing-masing kelompok terdiri 
atas 4 ekor. Tikus diadaptasikan selama satu minggu di laboratorium dengan suhu ruangan $26^{\circ} \mathrm{C}$, diberi pakan komersial dan air minum secara ad libitum. Setelah adaptasi, masing-masing tikus diberi perlakuan dengan pakan yang dicampur dengan tepung daun kelor msing-masing dengan konsentrasi $0 \%, 2,5 \%, 5 \%, 10 \%$, dan $20 \%$, selama 1 bulan. Pada akhir penelitian, semua tikus dibius menggunakan kloroform secara inhalasi, kemudian dilanjutkan pengambilan sampel darah melalui sinus orbitalis dengan mikrohematokrit. Sampel darah yang sudah dikoleksi menggunakan mikrohematokrit dibiarkan membeku selama 1-2 jam hingga terbentuk serum. Kemudian sesegera mungkin serum langsung dianalisis kadar urea dan kreatinin serum tikus wistar.

\section{Analisis Data}

Data kadar kreatinin dan urea dianalisis mengunakan sidik ragam (ANOVA). Jika perlakuan berpengaruh nyata dilanjutkan dengan uji Duncan dengan tingkat kepercayaan 5\%. Analisis dilakukan menggunakan software SPSS versi 17 (Sampurna, 2015).

\section{HASIL DAN PEMBAHASAN}

Hasil analisis kadar kreatinin dan urea pada pakan tikus percobaan yang diberi pakan tepung daun kelor pada berbagai konsentrasi $(0,2.5,5,10$, dan $20 \%)$ disajikan pada Tabel 1. dan Table 2.

Tabel 1.Kadar Kreatinin Serum Tikus Wistar

\begin{tabular}{cl}
\hline Perlakuan $(\%)$ & Rata-rata $(\mathrm{mg} / \mathrm{dl})$ \\
\hline 0 & $0,275 \pm 0,05^{\mathrm{a}}$ \\
2,5 & $0,300 \pm 0,00^{\mathrm{a}}$ \\
5 & $0,225 \pm 0,05^{\mathrm{a}}$ \\
10 & $0,275 \pm 0,05^{\mathrm{a}}$ \\
20 & $0,300 \pm 0,00^{\mathrm{a}}$ \\
\hline
\end{tabular}

Keterangan: Angka yang diikuti dengan huruf superscript yang sama ke arah kolom menunjukkan tidak berbeda nyata $(\mathrm{P}>0,05)$.

Pada Tabel 1 tampak bahwa perlakuan tepung daun kelor tidak berpengaruh nyata
( $\mathrm{P}>0,05)$ terhadap kadar kreatinin. Hasil yang diperoleh pada analisis kadar kreatinin antar kelompok dengan uji Anova dengan hasil $P=0,118$.

Hasil penelitian menunjukkan bahwa analisis kadar kreatinin serum tikus putih kelompok kontrol diperoleh hasil sebesar $0,275 \mathrm{mg} / \mathrm{dl}$ sedangkan kadar urea kelompok kontrol yang diperoleh sebesar 30,4 mg/dl. Sementara Maralla (2013) melaporkan kadar urea plasma pada tikus wistar normal berkisar 30,2 $\pm 0,7 \mathrm{mg} / \mathrm{dl}$. Pada tikus yang diberi perlakuan tepung daun kelor menunjukkan kadar urea meningkat dengan meningkatnya dosis tepung daun kelor. Menurut Wolfenshon dan Lloyd (2013), kadar kreatinin pada serum tikus wistar berkisar 2-3 mg/dl dan pada tikus yang diberi perlakuan tepung daun kelor meningkat tetapi masih dalam kadar normal dan tidak berpengaruh nyata. Namun demikian, adanya peningkatan kadar urea dan kreatinin dalam darah tidak selalu mengindikasikan adanya gangguan fungsi ginjal.

Kreatinin adalah produk akhir metabolisme kreatin di dalam otot. Secara metabolik kreatinin merupakan komponen tidak aktif yang kemudian berdifusi ke dalam plasma dan diekskresikan ke dalam urin. Wientarsih et al. (2012) menambahkan bahwa kreatinin merupakan metabolit keratin yang diekskresikan seluruhnya ke dalam urin melalui filtrasi glomerulus. Peningkatan kadar kreatinin dalam darah dapat digunakan untuk memperkirakan laju filtrasi glomerulus. Kadar kreatinin darah dapat menggambarkan fungsi ginjal secara lebih baik dan lebih stabil dibandingkan dengan kadar urea dalam darah. Kreatinin umumnya dianggap tidak dipengaruhi oleh asupan protein namun sebenarnya kadar protein dapat mempengaruhi kadar kreatinin tidak sebesar pengaruhnya terhadap kadar urea.

Pada penelitian ini kadar kreatinin serum tikus wistar mengalami perubahan. Pada konsentrasi 5\% kadar kreatinin 
mengalami penurunan jika dibandingkan dengan kelompok kontrol. Pada kadar 2,5\%, $10 \%$ dan $20 \%$ mengalami kenaikan jika dibandingkan dengan kelompok kontrol, tetapi kadar 10\% lebih rendah dibandingkan kadar 2,5\% dan $20 \%$. Sedangkan, pada kadar urea serum tikus kelompok dosis $2,5 \%$ dan $5 \%$ mengalami penurunan dibandingkan dengan kelompok kontrol. Kelompok $10 \%$ dan $20 \%$ mengalami kenaikan dibandingkan kelompok kontrol dan kelompok dosis $10 \%$ mengalami kenaikan yang signifikan. Amir et al. (2015) mengemukakan bahwa kenaikan kadar urea dalam darah bisa disebabkan oleh beberapa keadaan misalnya peningkatan katabolisme protein protein jaringan disertai dengan keseimbangan nitrogen yang negatif, pemecahan protein darah yang berlebihan, pengurangan ekskresi urea karena penurunan laju filtrasi glomerulus, dan pengaruh zat kimia toksik.

Tabel 2. Rataan Kadar Urea (mg/dl)

\begin{tabular}{cl}
\hline Perlakuan & Rata-rata $(\mathrm{mg} / \mathrm{dl})$ \\
\hline 0 & $30,400 \pm 5,12^{\mathrm{a}}$ \\
2,5 & $28,325 \pm 4,65^{\mathrm{a}}$ \\
5 & $28,475 \pm 2,42^{\mathrm{a}}$ \\
10 & $41,225 \pm 5,55^{\mathrm{b}}$ \\
20 & $31,900 \pm 0,20^{\mathrm{a}}$ \\
\hline
\end{tabular}

Keterangan: Angka yang diikuti dengan huruf superscript yang beda ke arah kolom menunjukkan berbeda nyata $(\mathrm{P}<0,05)$.

Pada Tabel 2 tampak bahwa perlakuan tepung daun kelor berpengaruh nyata terhadap kadar $(\mathrm{P}<0,05)$. Dari tabel kelompok 2,5 dan 5\% mendapatkan hasil yang lebih baik dari kelompok kontrol. Sedangakan kelompok 10 dan 20\% mendapat nilai yang lebih tinggi dari kelompok kontrol. Hasil yang diperoleh pada analisis kadar urea antar kelompok dengan uji Anova dengan hasil $P=0,04$ yang berarti kadar urea antar perlakuan berbeda nyata $(\mathrm{P}<0,05)$.

Pemeriksaan kadar urea dan kreatinin bertujuan untuk mengetahui adanya kelainan fungsi atau kerusakan ginjal. Rasyad (2012) menuliskan bahwa urea merupakan produk sisa hasil metabolisme protein yang utama. Hampir seluruh ureum dibentuk di dalam hati melalui suatu proses katabolisme protein. Kadar urea dalam darah merupakan gambaran keseimbangan antara pembentukan ureum dengan ekskresi urea oleh ginjal.

Sama halnya dengan kadar kreatinin, kadar urea juga memperoleh hasil yang naik turun dari analisis serum yang dilakukan. Hal ini, diduga karena perbedaan jumlah asupan pakan yang dikonsumsi setiap tikus. Pada penelitian ini, satu kandang percobaan terdiri dari empat ekor tikus wistar yang mana setiap tikus diberi pakan secara ad libitum, sehingga setiap ekor tikus mengkonsumsi dalam jumlah yang berbeda. Dalam satu kandang, tikus-tikus tersebut makan dari satu mangkuk yang sama. Jadi, ada tikus yang lebih banyak makan dibandingkan yang lain.

Tikus adalah hewan pengerat dan hewan pengerat biasanya lebih menyukai pakan yang berbentuk agak keras. Kemungkinan, ada beberapa ekor tikus yang mengkonsumsi lebih banyak dari tikus lainnya atau bisa juga satu kandang mengkonsumsi lebih banyak dari kandang lainnya, sehingga asupan nutrisinya berbeda dan lagi asupan proteinya akan berbeda. Selain dari itu ada beberapa faktor yang dapat mempengaruhi kecernaan makanan yaitu jenis kelamin, komposisi makanan, cara pengolahan pakan, dan jumlah pakan yang dikonsumsi oleh hewan (Sumaryono et al., 2008).

Beberapa faktor seperti banyaknya massa otot (laju metabolisme protein) dan aktivitas metabolisme tubuh dapat meningkatkan kadar kreatinin. Meningkatnya laju metabolisme protein setiap tikus tergantung dari jumlah protein yang dikonsumsi. Menurut Michael (2013), meskipun asupan protein mempengaruhi kreatinin, namun pengaruh tersebut tidak secara langsung karena kreatinin disintesis dari kreatin. Proses sintesis kreatin tersebut menggunakan asam amino esensial perkusor kreatinin yaitu arginin dan glisin 
dan asam amino esensial tersebut terkandung dalam tepung daun kelor. Jadi, pengaruh jumlah konsumsi pakan juga berpengaruh pada kadar kreatinin.

\section{SIMPULAN DAN SARAN}

\section{Simpulan}

Dari hasil penelitian yang diperoleh dapat disimpulakan bahwa tepung daun kelor tidak berpengaruh nyata terhadap kadar kreatinin serum tikus wistar, sementara berpengaruh nyata terhadap kadar urea serum tikus wistar.

\section{Saran}

Penelitian pemberian tepung daun kelor lebih dari konsentrasi $20 \%$ perlu dilakukan untuk melihat efeknya terhadap kadar urea dan kreatinin terhadap fungsi ginjal. Selain dari itu, perlakuan dan cara pemberian pakan setiap ekornya harus dilakukan secara terpisah agar jumlah pakan yang dikonsumsi setiap ekornya sama sehingga memperoleh hasil analisis yang lebih baik.

\section{DAFTAR PUSTAKA}

Alunat DES, Kardena IM, Suarsana IN. 2014. Pengaruh Konsumsi Urin Sapi Bali Terhadap Kadar Blood Urea Nitrogen, Kreatinin Serta Gambaran Histopatologi Ginjal Tikus. Bul. Vet. Udayana. 6(2): 169-173.

Amir N, Suprayitno E, Hardoko, Nursyam, H. 2015. Pengaruh Sipermetrin Pada Jambal Roti Terhadap Kadar Ureum Dan Kreatinin Tikus Wistar (Rattus Norvegicus). J. Ipteks PSP. 2(3): 283293.

Anwar F, Latif S, Ashraf M, Gilani AH. 2007. Moringa oleifera: A Food Plant with Multiple Medicinal Uses. Phytotherapy Res. 21: 17-25.

Dubey DK, Dora J, Kumar A, Gulsan RK. 2013. A Multipurpose Tree-Moringa oleifera. Int. J. Pharm. Chem. Sci. 2(1): 415-423.

Guevaraa AP, Vargasa C, Sakuraib H, Fujiwarab Y, Hashimotob K, Maokab T, Kozukac M, Itoc Y, Tokudad H,
Nishinod H. 1999. An antitumor promoter from Moringa oleifera Lam. Mutat. Res. 440: 181-188.

Laksmi NLGMC, Dada IKA, Damriyasa IM. 2014. Bioaktivitas Ekstrak Daun Tapakdara (Catharanthus roseus) terhadap Kadar Kreatinin dan Kadar Ureum Darah Tikus Putih (Rattus norvegicus). Bul. Vet. Udayana. 6(2): 147-152.

Maralla S. 2013. Effect of Ginger Extract Consumption On Renal Function during Ethanol Withdrawal InducedStress. Int. J. Innov. Res. Sci. Eng. Technol. 2(11): 6412-6418.

Michael. 2013. Pengaruh Ekstrak Metanol Daun Kesum (Polygonum Minus Huds.) Terhadap Peningkatan Kadar Kreatinin Dan Ureum Serum Tikus Putih Galur Wistar Terinduksi Sisplatin. Skripsi. Program Studi Farmasi Fakultas Kedokteran. Universitas Tanjungpura Pontianak.

Rasyad AA, Mahendra P, Hamdani Y. 2012. Uji Nefrotoksik dari Ekstrak Etanol Biji Mahoni (Swietenia mahagoni Jacq.) terhadap Tikus Putih Jantan Galur Wistar. J. Penelitian Sains. 15(2C): 79-82.

Sampurna IP. 2015. Peran Statistika dalam Meminimumkan Kesalahan pada Penelitian Ilmiah. Seminar Ilmiah. Fakultas Kedokteran Hewan. Universitas Udayana.

Sumaryono W, Wibowo AE, Ningsih S, Agustini K, Sumarny R, Amri F, Winarno H. 2008. Analisis UreaKreatinin Tikus Putih pasca Pemberian Ekstrak Buah Mahkota Dewa dan Herba Pegagan. J. Ilmu Kefarmasian Indonesia. 6(1): 35-40.

Wahyuni S, Asrikan MA, Sabana MCU, Sahara SWN, Murtiningsih T, Putriningrum R. 2013. Uji Manfaat Daun Kelor (Moringa Aloifera Lamk) Untuk Mengobati Penyakit Hepatitis B. J. KesMaDaSka. 4(2): 100-103.

Wihastuti TA, Sargowo D, Rohman MS. 2007. The Effect of Moringa oleifera 
Leaf Extract in Inhibition of $\mathrm{NF \kappa B}$ Activation, TNF- $\alpha$ and ICAM-1 Expression in Oxydized LDL treated HUVECS. J. Kardiologi Indonesia. 38(3): 181-188.

Wientarsih, I., R. Madyastuti, B. F. Prasetyo dan D. Firnanda. 2012. Gambaran Serum Ureum dan Kreatinin pada Tikus Putih yang Diberi Fraksi Etil Asetat Daun Alpukat. J. Vet. 13(1): 57-62.

Wolfenshon S, Lloyd M. 2013. Handbook of Laboratory Animal Management and Welfare. $3^{\text {rd }}$ Ed. Oxford: Blackwell Publishing. 